Application of Digital Elevation Models

To Delineate Drainage Areas and

Compute Hydrologic Characteristics

For Sites in the James River Basin,

North Dakota

United States

Geological

Survey

Water-Supply

Paper 2383

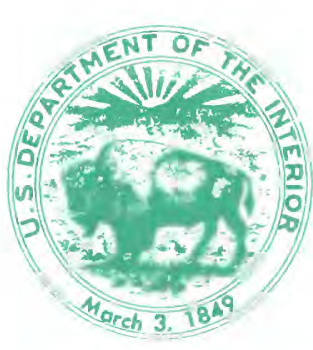





\title{
Application of Digital Elevation Models to Delineate Drainage Areas and Compute Hydrologic Characteristics For Sites in the James River Basin, North Dakota
}

\author{
By GREGG J. WICHE \\ U.S. Geological Survey
}

SUSAN K. JENSON, JOSEPH V. BAGLIO, and JULIA O. DOMINGUE EROS Data Center

Prepared in cooperation with the U.S. Bureau of Reclamation 


\section{U.S. DEPARTMENT OF THE INTERIOR MANUEL LUJAN, JR., Secretary}

\section{U.S. GEOLOGICAL SURVEY}

Dallas L. Peck, Director

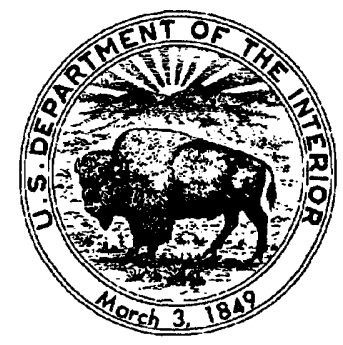

Any use of trade, product, or firm names in this publication is for descriptive purposes only and does not imply endorsement by the U.S. Government

For sale by

Book and Open-File Report Sales

U.S. Geological Survey

Federal Center, Box 25286

Denver, CO 80225

\section{Library of Congress Cataloging-in-Publication Data}

Application of digital elevation models to delineate drainage areas and compute hydrologic characteristics for sites in the James River basin, North Dakota / by Gregg J. Wiche ... [et al.] 2383)

p. cm. - (Water-supply paper / United States Geological Survey ;

"Prepared in cooperation with the U.S. Bureau of Reclamation."

Includes bibliographical references.

Supt. of Docs. no.: I 19.13:W2383

1. Flood forecasting-James River watershed (N.D. and

S.D.)-Maps. 2. Digital mapping. I. Wiche, Gregg J. II. United

States. Bureau of Reclamation. III. Series: U.S. Geological Survey water-supply paper ; 2383.

GB1399.4.J36A67 1992

$551.48^{\prime} 9^{\prime} 097833-\mathrm{dc} 20$

[551.7'66'09788] 


\section{CONTENTS}

Abstract 1

Introduction 1

Description of study area 2

Previous investigations 2

Hydrologic studies 2

Cartographic studies $\mathbf{3}$

Approach used to delineate drainage areas and compute hydrologic characteristics

Characteristics of test sites used to develop digital elevation models $\mathbf{5}$

Development, accuracy, and cost of digital elevation models $\mathbf{6}$

Development of computer programs used to process digital elevation model data 7

Procedure 18

Procedure $2 \quad 11$

Procedure $3 \quad 11$

Procedure $4 \quad 11$

Procedure $5 \quad 14$

Hydrologic characteristics 15

Depth, surface area, and storage volume relations

15

Comparison among test sites 17

Comparison among digital elevation models 18

Comparison of contributing and noncontributing drainage areas 19

Summary and conclusions 19

References 21

PLATE

[Plate is in pocket]

1. Maps showing drainage-area boundaries and outlet elevations of subbasins in the James River basin, North Dakota, computed using digital elevation models developed from aerial photographs

\section{FIGURES}

1. Map showing location of James River basin 3

2. Map showing location of five test sites used to develop digital elevation models 4

3. Flow chart of major tasks required to delineate drainage areas using digital elevation models $\mathbf{8}$

4-10. Matrix showing:

4. Cell elevations in a 20-row by 10-column subset of a sample digital elevation model 9

5. Cell elevations in a 20 -row by 10 -column subset of a modified digital elevation model $\mathbf{1 0}$

6. Difference in elevation obtained by subtracting cell elevations in the sample digital elevation model from cell elevations in the modified digital elevation model 
7. Unique nonzero values used to identify groups of cells that comprise depressions in the depression mask data set 13

8. Flow direction values assigned to cells in the sample digital elevation model 14

9. Eight possible flow directions assigned to a cell and their orientation 15

10. Assignment of cells in the sample digital elevation model to drainage subbasins 16

11. Schematic diagram of contributing and noncontributing subbasin linkages in test site 4 for a 3.0-inch runoff 22

\section{TABLES}

1. Cost of developing various digital elevation models for test site 47

2. Differences, in feet, among cell elevations in digital elevation models developed for test site 4 from 7.5-minute topographic maps, 4,800-foot aerial photographs, and 9,600-foot aerial photographs $\mathbf{8}$

3. Hydrologic characteristics computed from a sample digital elevation model

4. Drainage-basin linkages, outlet locations of common divides, and outlet elevations 17

5. Regression equations of depth, surface area, and storage volume relations for five test sites in the James River basin $\mathbf{1 7}$

6. Hydrologic characteristics computed using digital elevation models developed from 4,800-foot aerial photographs $\mathbf{1 8}$

7. Inflow to and outflow from subbasins in test site 4 for a 1.0-inch runoff computed using a digital elevation model developed from 9,600-foot aerial photographs 20

8. Inflow to and outflow from subbasins in test site 4 for a 3.0 -inch runoff computed using a digital elevation model developed from 9,600-foot aerial photographs

\section{SELECTED FACTORS FOR CONVERTING INCH-POUND UNITS TO METRIC UNITS}

For those readers who may prefer to use metric (International System) units rather than inch-pound units, the conversion factors for the terms used in this report are given below.

\begin{tabular}{lcl}
\hline Multiply inch-pound unit & By & To obtain metric unit \\
\hline Acre-foot & 1,233 & cubic meter \\
& 0.001233 & cubic hectometer \\
Cubic foot & 0.02832 & cubic meter \\
Foot & 0.3048 & meter \\
Inch & 25.4 & millimeter \\
Mile & 1.609 & kilometer \\
Square foot & 0.0929 & square meter \\
Square mile & 2.59 & square kilometer \\
\hline
\end{tabular}

Sea level: In this report "sea level" refers to the National Geodetic Vertical Datum of 1929 (NGVD of 1929) - a geodetic datum derived from a general adjustment of the first-order level nets of both the United States and Canada, formerly called Sea Level Datum of 1929. 


\title{
Application of Digital Elevation Models to Delineate Drainage Areas and Compute Hydrologic Characteristics for Sites in the James River Basin, North Dakota
}

\author{
By Gregg J. Wiche, \\ U.S. Geological Survey, and \\ Susan K. Jenson, Joseph V. Baglio, and Julia O. Domingue, \\ EROS Data Center
}

\section{ABSTRACT}

Understanding hydrologic characteristics of contributing and noncontributing drainage areas is a prerequisite for estimating the probable maximum flood. The U.S. Bureau of Reclamation, which is responsible for estimating the probable maximum flood into Jamestown Reservoir, needed more detailed drainage-area information than was readily available from topographic maps. The purpose of this study was to use digital elevation models in conjunction with special-purpose software to delineate drainage areas and compute hydrologic characteristics for five test sites in the James River basin, North Dakota.

Two digital elevation models were developed for each test site. The first model was developed from 7.5-minute topographic maps, and the second model was developed from 4,800-foot aerial photographs. In addition, a third digital elevation model was developed for test site 4 from 9,600-foot aerial photographs. The total cost of developing the digital elevation models for test site 4 ranged from $\$ 155$ per square mile when using 7.5-minute topographic maps to $\$ 740$ per square mile when using 4,800-foot aerial photographs.

The total drainage area delineated for the test sites ranged from 2.62 to 10.2 square miles. Storage volume of depressions having storage greater than 10 acre-feet ranged from 117 to 715 acre-feet per square mile.

The total runoff of subbasins contributing runoff to depressions in test site 4 was computed for a 1.0-inch runoff and a 3.0 -inch runoff. For a 1.0 -inch runoff, 0.40 square mile of the total 6.37-square-mile drainage area changed from noncontributing to contributing. For a 3.0-inch runoff, about 3.39 square miles changed from noncontributing to

Manuscript approved for publication, September 25, 1990. contributing. The percentage of drainage area that contributes runoff to depressions varies directly to the amount of precipitation and hydrologic characteristics in the basin.

\section{INTRODUCTION}

Understanding hydrologic characteristics of contributing and noncontributing drainage areas and accurate delineation of drainage areas are prerequisites for an accurate estimate of the probable maximum flood. The U.S. Bureau of Reclamation, which is responsible for estimating the probable maximum flood into Jamestown Reservoir, east-central North Dakota, currently is evaluating the hydraulic characteristics of Jamestown Dam and Reservoir under the Safety Evaluation of Existing Dams program. Delineation of drainage areas in the James River basin, however, historically has required a large amount of subjective judgment.

The drainage area at a specified point on a stream is the area, measured in a horizontal plane, that is enclosed by a topographic divide from which direct surface runoff drains into a stream (Sloss, 1971). In North Dakota, delineation of drainage areas in the James River basin was completed in 1952 by manually delineating drainage areas on 15 -minute topographic maps or county highway planning maps if topographic maps were not available. The drainage-area delineation was revised in 1967 by delineating areas on 7.5-minute topographic maps or county highway planning maps.

Two major problems occur when delineating drainage areas in the James River basin using conventional techniques. First, determination of drainage-area boundaries 
is difficult, especially at the divide where the James River, Missouri River, and Hudson Bay drainages meet. Near the divide, the topography is flat and drainage channels are poorly defined. Second, differentiating between areas that contribute surface runoff to the James River and areas that do not contribute surface runoff, but are still within the James River basin, is difficult. Noncontributing areas do provide surface runoff during some wet years; but, during most years, much of the runoff is stored in the many depressions and small lakes in the basin and is later lost as evapotranspiration or becomes ground-water recharge.

The purpose of this study is to use digital elevation models in conjunction with special-purpose software to delineate drainage areas and compute hydrologic characteristics for five test sites in the James River basin. The U.S. Geological Survey, in cooperation with the U.S. Bureau of Reclamation, conducted a drainage-area delineation study to compute the hydrologic characteristics for the five test sites, to compare the differences among the computed characteristics, and to test the accuracy of various digital elevation models. This report presents the results of the study.

Digital elevation models for all test sites were developed from data collected during field surveys at the test sites; vertical and horizontal controls also were established. The controls were used in conjunction with aerial photographs of the test sites to develop digital elevation models.

A collection of computer programs was developed to process digital elevation model data and to compute hydrologic characteristics. Spatial analysis programs were used to display the digital elevation models and to plot hydrologic characteristics such as drainage-area boundaries.

\section{DESCRIPTION OF STUDY AREA}

The James River, about 747 miles in length, drains parts of east-central North Dakota and South Dakota (fig. 1). The James River basin encompasses about 21,100 square miles, of which about 6,200 square miles is located in North Dakota and 14,900 square miles is located in South Dakota. The headwaters of the James River are located in the Coteau du Missouri in Wells County, N. Dak. (fig. 2). The Coteau du Missouri is a band of morainic hills about 30 miles wide and 800 miles long extending from east-central South Dakota, through North Dakota, and into southwestern Saskatchewan (Clayton, 1967). The Coteau consists of closely spaced hummocks alternating with marshy depressions called prairie potholes. Topography in the Coteau provides for the development of relatively deep depressions that have large amounts of storage. From the headwaters, the James River extends about 100 miles to Arrowwood National Wildlife Refuge (fig. 2). Upstream of the refuge, discharge is low or nonexistent during much of each year. Jamestown Reservoir, located immediately downstream of the refuge in a narrow valley, was created by the completion of Jamestown Dam in 1953. The drainage area upstream of Jamestown Reservoir is 1,760 square miles, of which about 1,010 square miles is considered noncontributing. Pipestem Creek, a major tributary to the James River, enters the James River 1 mile downstream of Jamestown Reservoir. Pipestem Creek has been regulated since the completion of Pipestem Dam in 1973.

\section{PREVIOUS INVESTIGATIONS}

\section{Hydrologic Studies}

In the late 1950's, a need for additional hydrologic information pertaining to prairie potholes developed because depressional storage areas were being drained for agricultural use. Conservationists feared that continued drainage would reduce the numbers of migratory waterfowl by destroying breeding grounds (Eisenlohr, 1972). In response to the need for additional hydrologic information, the U.S. Geological Survey conducted studies from 1959 through 1968 to define the hydrology of prairie potholes. Evaporation and transpiration losses were studied by Shjeflo (1968) and by Eisenlohr (1972), the effects of ground-water movement were investigated by Sloan (1972), and the vegetation and water quality of prairie potholes were investigated by Stewart and Kantrud (1972). All these studies were directed specifically at computing individual hydrologic characteristics. Little work was done to determine drainage-basin linkages among depressional storage areas.

Haan and Johnson (1968a) indicated that damage from extreme floods on the upper Mississippi River in the spring of 1965 helped focus attention on how areas in southern Minnesota and north-central Iowa, characterized by numerous potholes, affect streamflow. As a result of the floods, engineers in the Agricultural Engineering Department at Iowa State University began a study to develop a watershed model that could be used on small watersheds to determine the effect of draining potholes. As part of this study, Haan (1967) investigated the hydraulics of watersheds characterized by depressional storage in north-central Iowa. Haan and Johnson (1967) developed the following regression relations between storage volume, surface area, and depth of depressions:

$$
V=0.34 A^{1.44}
$$

where

$V=$ storage volume of depression, in acre-feet; and 


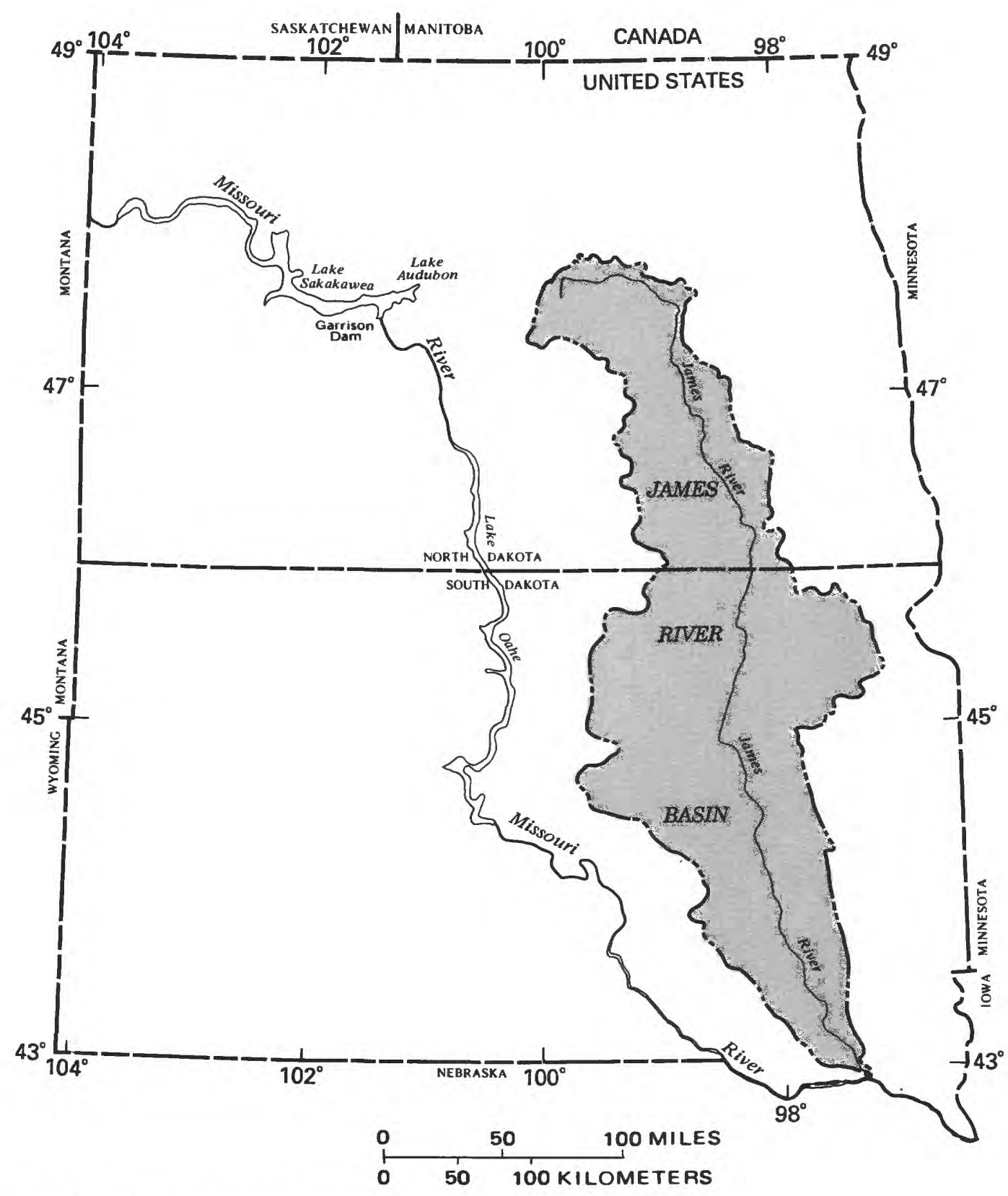

Figure 1. Location of James River basin.

and

$A=$ surface area of depression, in acres;

$$
V=0.49 D^{2.42}
$$

where

$D=$ depth of depression, in feet.

Equation 1 has a coefficient of determination of 0.92 and a standard error of estimate of 0.23 . Equation 2 has a coefficient of determination of 0.80 and a standard error of estimate of 0.40 .

The watershed model developed at Iowa State University is discussed by Haan and Johnson (1968b), DeBoer and Johnson (1971), and Campbell and Johnson
(1975). The primary function of the model is to simulate watershed discharge and soil moisture continuously throughout the growing season.

\section{Cartographic Studies}

Advances in computing hydrologic characteristics for a basin have been based on a form of elevation information commonly known as a digital elevation model, which is map data converted to a digital form. The U.S. Geological Survey distributes two gridded elevation data sets. The first 


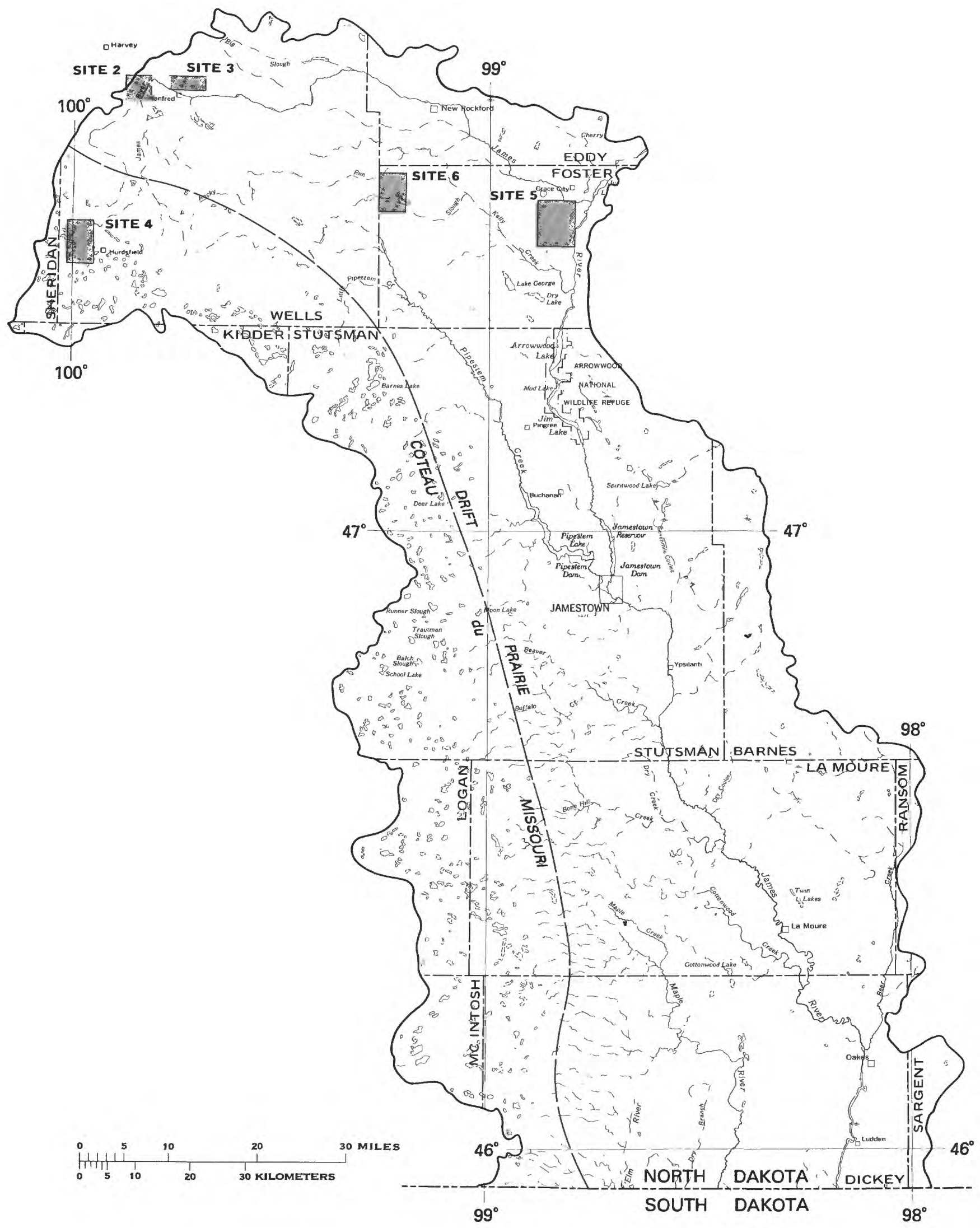

Figure 2. Location of five test sites used to develop digital elevation models. 
gridded elevation data set, the Digital Terrain Model, was developed by the Defense Mapping Agency from 1:250,000scale topographic maps (Elassal and Caruso, 1983). The Digital Terrain Model covers 1- by 1-degree areas and has a grid-cell size (surface area) of 3 arc-seconds. Three arc-seconds represents about 295 feet in the north-south axis and a variable dimension in the east-west axis due to convergence of the meridians (about 207 feet at 47 degrees north latitude). Mark (1983) indicated that because the elevations were obtained by interpolation from digitized topographic contours, the effective resolution is sometimes not as good as the cell size indicates.

The second gridded elevation data set, which was developed by the U.S. Geological Survey, is the digital elevation model that corresponds in coverage to standard 1:24,000-scale 7.5-minute topographic maps. The digital elevation model has a 91.4- by 91.4-foot cell size. Each cell is assigned a cell identifier, location, and ground-surface elevation. The characteristics of the model and the techniques used to develop the model are discussed by Elassal and Caruso (1983).

Many advances have been made in computing hydrologic characteristics from digital elevation model data. Collins (1975) and Collins and Moon (1981) used an algorithm to determine drainage-basin divides between depressions, surface area of drainage basins, storage volume of depressions, and outlet elevations. Collins (1975) identified the drainage basin by sorting and ranking all gridcell elevations in ascending order. The lowest elevation (rank 1) is the outflow of a drainage basin. If the grid cell designated rank 2 is not a neighbor of the grid cell designated rank 1 , then the grid cell designated rank 2 must be a separate drainage basin. By connecting grid cells in this sequence, all points on the grid are assigned a drainage basin.

Marks and others (1984) developed a technique that applied recursion to delineate drainage basins and link areas of internal drainage to their respective watersheds. Jenson (1985) developed procedures to build drainage patterns from digital elevation models and determine drainage-basin boundaries by labeling cells in an uphill fashion until a ridgeline is encountered.

Miller and Goldberg (1984) described procedures necessary to delineate a drainage basin using two general types of data from topographic maps-digital line-graph data and digital elevation model data. Digital line-graph data are developed by extracting hydrographic features, such as streams, lakes, and wetlands, from 7.5-minute topographic maps and expressing these features as a set of nodes connected by line segments. The digital line-graph data file is composed of three separate but related elements - nodes, line segments, and areas. Goldberg (U.S. Geological Survey, written commun., 1987) developed software to convert digital line-graph data, which represent drainage channels, into a raster format. Miller and Goldberg
(1984) developed software linking digital line-graph data to digital elevation model data to determine where overland flow from each cell in the digital elevation model enters the stream network identified by the digital line graph.

Douglas (1986) discussed methods used to store topographic data in digital format. Douglas (1986) also reviewed and discussed strengths and weaknesses of many computer programs used to delineate stream channels and drainage-basin boundaries.

Each of the studies mentioned previously provided new methods of computing hydrologic characteristics from digital elevation models. However, none of the studies provides a technique to link the myriad of subbasins in the James River basin. New algorithms were developed during this study so that hydrologic characteristics in the James River basin can be computed from digital elevation models.

\section{APPROACH USED TO DELINEATE DRAINAGE AREAS AND COMPUTE HYDROLOGIC CHARACTERISTICS}

The costs and computer resources required to develop digital elevation models and compute hydrologic characteristics for the entire James River basin upstream of Jamestown Dam were prohibitive. About $2.0 \times 10^{7}$ cells (50by 50 -foot cell size) would be required to represent the James River basin upstream of Jamestown Dam. Consequently, five test sites (pl. 1, parts $A-E$ ) that are representative of the topography and the drainage patterns of the James River basin (fig. 2) were selected to develop the digital elevation models. The test sites were selected using the following criteria: (1) 7.5-minute topographic maps were available for each site, (2) the sites represented areal coverage throughout the basin upstream of Jamestown Dam, (3) the sites represented a range in depression surface area and in depression densities, and (4) the sites included several individual subbasins. Originally, six test sites were chosen, but, after final selections were made, test site 1 was eliminated.

\section{Characteristics of Test Sites Used to Develop Digital Elevation Models}

All test sites except test site 5 have a 50 - by 50 -foot cell size. For test site 5 , the cell size is 55 by 55 feet, which was the minimum size that could be used to provide coverage of test site 5 and not exceed maximum dimension size allowed in computer programs used to convert digitized contours to a digital elevation model.

Test site 2, which is located in the western part of the study area about 4 miles southeast of Harvey, N. Dak., represents a surface area of about 9 square miles. The James 
River flows through the southeastern part of the test site. Depressions in test site 2 generally range in size from small to medium.

Test site 3, which is located about 1 mile north of Manfred, N. Dak., represents a surface area of about 9.5 square miles. Variously sized depressions are densely spaced throughout the test site. The outlet from any depression in test site 3 spills directly into the downstream depression. There are few swales connecting the depressions.

Test site 4, which is located in the Coteau du Missouri about 1 mile west of Hurdsfield, N. Dak., near the headwaters of the James River, represents a surface area of about 12.4 square miles. Topography in the Coteau provides for the development of relatively deep depressions that have large amounts of storage.

Test site 5 , which is located about 3 miles southwest of Grace City, N. Dak., represents a surface area of about 21.6 square miles. Depressions in test site 5 generally range in size from medium to large.

Test site 6, which is located in the northwestern corner of Foster County, N. Dak., represents a surface area of about 12.3 square miles. Depressions ranging in size from small to medium are densely spaced throughout the test site. Because of the close spacing of the depressions, there are few swales connecting them.

\section{Development, Accuracy, and Cost of Digital Elevation Models}

Two digital elevation models were developed for each test site. The first digital elevation model was developed from digitized contours of 7.5-minute topographic maps. The second digital elevation model was developed from aerial photographs taken at 4,800 feet above ground surface. In addition, a third digital elevation model was developed for test site 4 from aerial photographs taken at 9,600 feet above ground surface. Aerial photographs were obtained for each test site to determine if digital elevation models developed from different source materials provide significantly different hydrologic characteristics.

The boundaries of each test site were marked on the appropriate 7.5-minute topographic maps, and digital elevation models were developed by manually digitizing contours on the map. The 7.5-minute topographic maps, which were field sketched in 1950, have either a 5- or 10-foot contour interval. Automatic techniques are available to scan and digitize topographic maps, but the test sites were not large enough to warrant the use of these techniques. Output from the digitizing process is a two-dimensional vector file. This vector file is input to a computer program
$\left(\mathrm{ZYCOR}^{1}\right)$ consisting of mathematical subroutines that convert the data to a fixed-grid digital elevation model. Digital elevation models for all test sites were developed by the U.S. Geological Survey. Digital elevation model data and computer programs used to process the data are stored on computer files at the U.S. Geological Survey, Earth Resources Observation Systems (EROS) Data Center, Sioux Falls, S. Dak.

Developing digital elevation models from aerial photographs required substantially more effort than developing digital elevation models from topographic maps. Vertical control within 0.25 foot and horizontal control within 40 feet were established by personnel from the Midcontinent Mapping Center who conducted field surveys of the test sites. Horizontal control points that were field surveyed had to be transferred to the aerial photographs, and additional control points were established by aerotriangulation techniques. Contours were digitized manually from the aerial photographs on stereo plotters, and data were encoded directly into a two-dimensional vector file. A 2-foot contour interval was used. The vector file was used as input to a computer program (ZYCOR) to develop the digital elevation model.

A comparison was made between the costs required to produce digital elevation models developed from the different source materials for test site 4 because three digital elevation models are available for this test site. In this study, the assumption was made that digital elevation models developed from 4,800-foot aerial photographs are the most accurate followed by digital elevation models developed from 9,600-foot aerial photographs. The total cost of developing a digital elevation model for test site 4 from 7.5-minute topographic maps averaged $\$ 155$ per square mile (table 1). The cost of digitizing the maps was about $\$ 54$ per square mile (Goldberg and others, 1987). The total cost of developing a digital elevation model for test site 4 from 4,800 -foot aerial photographs was about $\$ 740$ per square mile. The cost of digitizing the photographs was about $\$ 396$ per square mile. The total cost of developing a digital elevation model for test site 4 from 9,600-foot aerial photographs was about $\$ 520$ dollars per square mile. The cost of digitizing the photographs was about $\$ 174$ dollars per square mile.

Vertical accuracies of the different digital elevation models for test site 4 were tested to determine overall accuracy. Each digital elevation model was compared to a set of ground-control elevations that were obtained during field surveys in November 1985. Additional ground-control elevations were established using photogrammetric techniques and aerotriangulation. About 254 ground-control elevations were established for the digital elevation model

\footnotetext{
${ }^{1}$ The use of brand names in this report is for identification purposes only and does not imply endorsement by the U.S. Geological Survey.
} 
Table 1. Cost of developing various digital elevation models for test site 4

Technique used to develop

digital elevation model Estimated cost ${ }^{2}$ per square mile

\begin{tabular}{ll}
\hline 7.5 -minute topographic maps & $\$ 155$ \\
4,800 -foot aerial photographs & 2740 \\
9,600 -foot aerial photographs & 2520 \\
\hline
\end{tabular}

'Based on 1987 dollars.

${ }^{2}$ Includes $\$ 82$ per square mile for aerial photographs.

developed from 7.5-minute topographic maps. About 1,380 ground-control elevations were established for the digital elevation models developed from 4,800-foot and 9,600-foot aerial photographs. Absolute accuracy of the ground-control elevations is \pm 1.5 feet (Goldberg and others, 1987). Ground-control elevations were compared to the elevation of the nearest cell to compute the root-mean-square error. The root-mean-square error is 4.6 feet for the digital elevation model developed from 7.5-minute topographic maps, 1.0 foot for the model developed from 4,800-foot aerial photographs, and 2.3 feet for the model developed from 9,600-foot aerial photographs.

Another test was performed to compare the surfaces of the different digital elevation models for test site 4. Cell elevations in a digital elevation model were subtracted from corresponding cell elevations in another model. This test was used to compare the relative accuracy of the digital elevation models and to indicate whether differences could occur in computed hydrologic characteristics, such as storage volume, surface area versus depth, and outlet elevations. Cell elevations in the digital elevation model developed from 9,600-foot aerial photographs were subtracted from corresponding cell elevations in the digital elevation model developed from 7.5-minute topographic maps. The 25th percentile of the differences is -2.46 feet, and the 75th percentile is 2.91 feet (table 2). The mean difference is 0.48 foot. Cell elevations in the digital elevation model developed from 4,800-foot aerial photographs were subtracted from corresponding cell elevations in the digital elevation model developed from 7.5-minute topographic maps. The 25 th percentile of the differences is -0.90 foot, and the 75 th percentile is 4.27 feet. The mean difference is 1.79 feet. Cell elevations in the digital elevation model developed from 9,600-foot aerial photographs were subtracted from corresponding cell elevations in the digital elevation model developed from 4,800 -foot aerial photographs. The 25 th percentile of the differences is -2.68 feet, and the 75 th percentile is 0.10 foot. The mean difference is -1.31 feet. Differences in cell elevations are less between the model developed from 9,600-foot aerial photographs and the model developed from 4,800-foot aerial photographs than between the models developed from 4,800-foot and 9,600-foot aerial photographs and the model developed from 7.5-minute topographic maps (table 2).

The absolute accuracy provides an indication of how well cell elevations in different digital elevation models correspond to the true elevation of the topography. The relative accuracy is an indicator of how well the digital elevation models represent topographic features in the test sites. The digital elevation model developed for test site 4 from 4,800-foot aerial photographs had the best absolute accuracy. The limited comparison of the relative accuracy completed for this study indicates that the surfaces of digital elevation models developed for test site 4 from 4,800-foot and 9,600-foot aerial photographs exhibit more similarities than the surfaces of digital elevation models developed from 4,800-foot aerial photographs and 7.5-minute topographic maps and the surfaces of digital elevation models developed from 9,600-foot aerial photographs and 7.5-minute topographic maps.

\section{Development of Computer Programs Used to Process Digital Elevation Model Data}

Major tasks required to delineate drainage areas using digital elevation models are shown in figure 3. A collection of computer programs has been developed at the EROS Data Center to complete many of the tasks outlined in figure 3 and to compute hydrologic characteristics from digital elevation model data. The computer programs are interfaced to, and work with, general-purpose spatial analysis programs. The general-purpose spatial analysis programs are necessary for displaying the digital elevation models and also may be used to plot hydrologic characteristics, such as drainage-area boundaries, that have been developed from 
Table 2. Differences, in feet, among cell elevations in digital elevation models developed for test site 4 from 7.5 -minute topographic maps, 4,800-foot aerial photographs, and 9,600-foot aerial photographs

\begin{tabular}{|c|c|c|c|c|c|c|}
\hline & Minimum & 25 th & percentile & Mean & 75th percentile & Maximum \\
\hline $\begin{array}{l}\text { Cell elevations in digital elevation } \\
\text { model developed from } 7.5 \text {-minute } \\
\text { topographic maps minus cell } \\
\text { elevations in digital elevation } \\
\text { model developed from } 9,600 \text {-foot } \\
\text { aerial photographs }\end{array}$ & -29.2 & & -2.46 & 0.48 & 2.91 & 25.9 \\
\hline $\begin{array}{l}\text { Cell elevations in digital elevation } \\
\text { model developed from } 7.5 \text {-minute } \\
\text { topographic maps minus cell } \\
\text { elevations in digital elevation } \\
\text { model developed from } 4,800 \text {-foot } \\
\text { aerial photographs }\end{array}$ & -22.0 & & -.90 & 1.79 & 4.27 & 23.5 \\
\hline $\begin{array}{l}\text { Cell elevations in digital elevation } \\
\text { model developed from } 4,800 \text {-foot } \\
\text { aerial photographs minus cell } \\
\text { elevations in digital elevation } \\
\text { model developed from } 9,600 \text {-foot } \\
\text { aerial photographs }\end{array}$ & -13.8 & & -2.68 & -1.31 & .10 & 13.0 \\
\hline
\end{tabular}

ACQUIRE AERIAL PHOTOGRAPHS OR TOPOGRAPHIC MAPS $\checkmark$ CONSTRUCT DIGITAL ELEVATION MODEL $\checkmark$ DELINEATE DEPRESSIONS $\checkmark 3$

SELECT SUBSET OF DEPRESSIONS THAT EXCEED A STORAGE VOLUME THRESHOLD \

VERIFY SUBSET SELECTION BY VISUAL INSPECTION AND REFINE SUBSET SELECTION \3

DELINEATE DRAINAGE-AREA BOUNDARIES AND CALCULATE OUTLET LOCATIONS, ELEVATIONS, AND OTHER DESIRED HYDROLOGIC CHARACTERISTICS OF THE DEPRESSIONS 3

PLOT DRAINAGE-AREA BOUNDARIES, SURFACE AREA OF THE DEPRESSION, AND OUTLET LOCATION FOR VISUAL INSPECTION

Figure 3. Major tasks required to delineate drainage areas using digital elevation models.

digital elevation model data. Many of the computer programs were available before this study began (Jenson, 1985); however, several computer programs had to be modified or developed. These computer programs are stored on computer files at the EROS Data Center.

Digital elevation model data developed for the five test sites were processed in five major sequential procedures:
(1) Fill the depressions by simulating a cell elevation equal to the outlet elevation.

(2) Label the depressions and compute their hydrologic characteristics.

(3) Select the depressions to be analyzed.

(4) Delineate the drainage areas containing the selected depressions.

(5) Compute the hydrologic characteristics for the subbasins.

A 20 -row by 10 -column subset of a sample digital elevation model having a 1 - by 1 -foot cell size will be used to illustrate the five procedures. Cell elevations in the subset are shown in figure 4.

\section{Procedure 1}

The function of procedure 1 is to fill depressions by simulating cell elevations equal to outlet elevations to develop a digital elevation model output surface similar to the input surface. Elevations of cells in the depressions are increased (analogous to filling) to the minimum cell elevation on the rim of the depression. The minimum cell elevation is the outlet elevation from the depression. Thus, each cell in the output surface will have at least one monotonically decreasing path of cells leading to the edge of the data set. A path is composed of cells that are adjacent horizontally, vertically, or diagonally (fig. 4) and that have cell elevations that are monotonically decreasing. Cell 
Column

\begin{tabular}{|c|c|c|c|c|c|c|c|c|c|c|}
\hline Row & 1 & 2 & 3 & 4 & 5 & 6 & 7 & 8 & 9 & 10 \\
\hline 1 & 70 & 52 & 44 & 35 & 29 & 29 & 39 & 48 & 55 & 62 \\
\hline 2 & 79 & 60 & 46 & 35 & 27 & 26 & 35 & 43 & 47 & 52 \\
\hline 3 & 88 & 67 & 52 & 38 & 27 & 25 & 30 & 34 & 37 & 39 \\
\hline 4 & 95 & 72 & 57 & 43 & 30 & 24 & 26 & 30 & 36 & 41 \\
\hline 5 & 91 & 67 & 52 & 41 & 31 & 23 & 25 & 32 & 43 & 53 \\
\hline 6 & 82 & 63 & 48 & 38 & 32 & 23 & 24 & 34 & 48 & 61 \\
\hline 7 & 67 & 57 & 47 & 38 & 32 & 22 & 27 & 40 & 53 & 66 \\
\hline 8 & 54 & 45 & 40 & 36 & 30 & -25 & 30 & 42 & 54 & 69 \\
\hline 9 & 61 & 43 & 36 & 30 & 8 & 21 & 25 & 34 & 47 & 62 \\
\hline 10 & 67 & 51 & 42 & 33 & 26 & -20 & 23 & 29 & 41 & 56 \\
\hline 11 & 73 & 62 & 51 & 41 & 30 & 21 & 20 & 25 & 37 & 49 \\
\hline 12 & 60 & 48 & 43 & 37 & 29 & 20 & 18 & 22 & 31 & 43 \\
\hline 13 & 50 & 42 & 45 & 40 & 31 & 23 & 19 & 17 & 24 & 35 \\
\hline 14 & 60 & 56 & 57 & 51 & 40 & 27 & 18 & 18 & 21 & 32 \\
\hline 15 & 77 & 73 & 73 & 64 & 50 & 34 & 22 & 18 & 21 & 31 \\
\hline 16 & 95 & 92 & 86 & 75 & 60 & 42 & 27 & 18 & 19 & 25 \\
\hline 17 & 99 & 96 & 88 & 79 & 66 & 49 & 32 & 21 & 19 & 23 \\
\hline 18 & 89 & 77 & 70 & 65 & 58 & 45 & 30 & 18 & 18 & 24 \\
\hline 19 & 72 & 59 & 52 & 48 & 46 & 37 & 24 & 14 & 16 & 21 \\
\hline 20 & 62 & 51 & 45 & 37 & 34 & 28 & 19 & 13 & 18 & 25 \\
\hline
\end{tabular}

\section{EXPLANATION}

\section{POTENTIAL FLOW DIRECTION}

\section{CALCULATED FLOW DIRECTION}

Figure 4. Cell elevations in a 20 -row by 10 -column subset of a sample digital elevation model.

elevations in the modified digital elevation model developed by procedure 1 are shown in figure 5 .

A new computer program was developed to accomplish procedure 1. Jenson and Trautwein (1987) and Jenson and Domingue (1988) documented applications of the program other than those used in this study. In earlier studies by Jenson (1985), drainage characteristics were assumed to be defined primarily by stream channels, and a computer program to analyze depressions was not required. However, in this study, depressions and their associated drainage areas are the main features of interest.
In order to accommodate large digital elevation models, the computer program used in procedure 1 was designed to operate in two modes. In the first mode, which is memory intensive, digital elevation model data are processed by finding and filling depressions wholly contained in a 100 -column by 100 -row block. If an outlet for a depression has not been located within the 100-column by 100-row block, then the depression is not wholly contained within the block. In the first mode, the block is stored and processed completely in memory. In the second mode, which is reading and writing intensive, the entire 


\begin{tabular}{|c|c|c|c|c|c|c|c|c|c|c|}
\hline Row & 1 & 2 & 3 & 4 & 5 & 6 & 7 & 8 & 9 & 10 \\
\hline 1 & 70 & 52 & 44 & 35 & 29 & 29 & 39 & 48 & 55 & 62 \\
\hline 2 & 79 & 60 & 46 & 35 & 27 & 26 & 35 & 43 & 47 & 52 \\
\hline 3 & 88 & 67 & 52 & 38 & 27 & 25 & 30 & 34 & 37 & 39 \\
\hline 4 & 95 & 72 & 57 & 43 & 30 & 25 & 26 & 30 & 36 & 41 \\
\hline 5 & 91 & 67 & 52 & 41 & 31 & 25 & 25 & 32 & 43 & 53 \\
\hline 6 & 82 & 63 & 48 & 38 & 32 & 25 & 25 & 34 & 48 & 61 \\
\hline 7 & 67 & 57 & 47 & 38 & 32 & 25 & 27 & 40 & 53 & 66 \\
\hline 8 & 54 & 45 & 40 & 36 & 30 & 25 & 30 & 42 & 54 & 69 \\
\hline 9 & 61 & 43 & 36 & 30 & 26 & 21 & 25 & 34 & 47 & 62 \\
\hline 10 & 67 & 51 & 42 & 33 & 26 & 20 & 23 & 29 & 41 & 56 \\
\hline 11 & 73 & 62 & 51 & 41 & 30 & 21 & 20 & 25 & 37 & 49 \\
\hline 12 & 60 & 48 & 43 & 37 & 29 & 20 & 19 & 22 & 31 & 43 \\
\hline 13 & 50 & 43 & 45 & 40 & 31 & 23 & 19 & 19 & 24 & 35 \\
\hline 14 & 60 & 56 & 57 & 51 & 40 & 27 & 19 & 19 & 21 & 32 \\
\hline 15 & 77 & 73 & 73 & 64 & 50 & 34 & 22 & 19 & 21 & 31 \\
\hline 16 & 95 & 92 & 86 & 75 & 60 & 42 & 27 & 19 & 19 & 25 \\
\hline 17 & 99 & 96 & 88 & 79 & 66 & 49 & 32 & 21 & 19 & 23 \\
\hline 18 & 89 & 77 & 70 & 65 & 58 & 45 & 30 & 18 & 18 & 24 \\
\hline 19 & 72 & 59 & 52 & 48 & 46 & 37 & 24 & 14 & 16 & 21 \\
\hline 20 & 62 & 51 & 45 & 37 & 34 & 28 & 19 & 13 & 18 & 25 \\
\hline
\end{tabular}

\section{EXPLANATION}

\section{DENOTES AN INCREASE IN CELL ELEVATION}

Figure 5. Cell elevations in a 20-row by 10-column subset of a modified digital elevation model.

digital elevation model is processed iteratively by reading from and writing to a disk file. Only three rows of a $n$-column block are stored and processed at a time. Initially, digital elevation model data are processed in the first mode, thereby filling all depressions comprised of cells that do not have coordinates evenly divisible by 100 . An intermediate data set produced by the first mode is used as input to the second mode to fill the remaining depressions. Filling the depression initially using the first mode and then finishing using the second mode is the most efficient use of computer time.
The method used to increase elevations of cells in the depression to the outlet elevation from the depression is the same for both modes. Steps completed during procedure 1 for each 100 -column by 100 -row block are as follow:

(1) Mark all cells on the block edges as having a path to the edge. All cells on the edges need to be marked because they may be in the interior of the digital elevation model.

(2) Mark all cells that are neighboring marked cells and that have an equal or greater elevation. 
(3) Repeat step 2 until all possible cells have been marked.

(4) Find and label all eight-way connected groups of unmarked cells so that each group has the maximum possible area. An eight-way connected group is a center cell connected to four adjacent cells by common side and to four cells that touch the corners of the center cell.

(5) If no eight-way connected groups of unmarked cells are found in step 4, end the procedure. If eight-way connected groups are found in step 4, record for each group the minimum cell elevation from the neighboring marked cells. The minimum cell elevation from the neighboring marked cells is the outlet elevation for the eight-way connected group of unmarked cells.

(6) Check the cell elevation of each cell in each eight-way connected group to determine if the cell elevation is less than the group's outlet elevation. If the cell elevation is less than the outlet elevation, set the cell elevation equal to the outlet elevation.

(7) Repeat procedure starting at step 2 .

\section{Procedure 2}

The function of procedure 2 is to label all depressions and compute hydrologic characteristics such as storage volume and surface area of depressions. One of the products developed in this procedure is a depression mask data set. In the depression mask data set, all cell elevations are set equal to zero except when a cell is contained in a depression and, therefore, the cell elevation is equal to the depression label. A difference data set (fig. 6) was computed by subtracting cell elevations in the sample digital elevation model (fig. 4) from cell elevations in the modified digital elevation model that were increased to the outlet elevation (fig. 5). Cells that have elevations greater than zero in the difference data set are members of depressions. In order to identify depressions as features that consist of many connected cells, the cells that comprise each depression are grouped and labeled in the depression mask data set (fig. 7) with a value unique to the depression.

Hydrologic characteristics of the depressions are computed after the difference data set and the depression mask data set have been developed. The characteristics are stored in a computer file where the first entry in a line is a unique depression identification number and subsequent entries in the line are characteristics of the depression. The storage volume of a cell is equal to the surface area (cell size) of a cell multiplied by the depth of the cell, which is obtained from the difference data set (fig. 6). The total storage volume of a depression is equal to the storage volume of all cells in the depression. The surface area of a depression is computed by obtaining the number of cells that have a unique depression label and then multiplying this number by the surface area of a cell. Hydrologic characteristics computed from the sample digital elevation model discussed previously are listed in table 3 .

\section{Procedure 3}

The function of procedure 3 is to select the depressions to be included in the drainage network. The selection process is dependent on the level of detail needed by the user. Depressions were selected based on storage volume, surface area, and visual inspection. A table of the depression identification numbers and attributes was constructed and the depressions were sorted by storage volume in descending order. In this study, a storage volume threshold of 20 acre-feet was used to select about 20 depressions per test site. The selected depressions were plotted to determine their relations in the drainage network. Some depressions that met the storage volume threshold criterion were not selected because they were located close to the edge of the digital elevation model and their drainage area could not be delineated completely or they were not connected to other depressions in the test site. Some depressions were retained even though the storage volume at the outlet elevation was less than 20 acre-feet because a visual inspection indicated the depressions were significant features and integral to the drainage network.

\section{Procedure 4}

The function of procedure 4 is to delineate areas draining to the depressions selected in procedure 3 . The delineation process uses the depression mask data set (fig. 7), a list of depressions selected in procedure 3 , and the modified digital elevation model (fig. 5). To initialize the drainage area mask, the depression mask data set is copied and the cell elevations in those depressions not selected in procedure 3 are set to zero.

The modified digital elevation model that had cell elevations increased to the outlet elevation from the depression (fig. 5) is used to create a flow direction data set (fig. 8). Flow direction for a cell is the direction water will flow out of a cell. The direction is computed based on the orientation of one of the eight cells neighboring the center cell. Eight possible flow directions and their orientation are shown in figure 9 . For example, if the flow direction for a cell is north, its value will be 128 .

Three possible conditions must be considered when determining the flow direction for a cell. The first condition is when only one of the eight neighboring cells has the greatest distance-weighted decrease in elevation. The distance-weighted decrease in elevation from the center cell to a neighboring cell is computed using the equations

$$
D C O=\frac{C E-C O}{\sqrt{2}}
$$




\begin{tabular}{|c|c|c|c|c|c|c|c|c|c|c|}
\hline Row & 1 & 2 & 3 & 4 & 5 & 6 & 7 & 8 & 9 & 10 \\
\hline 1 & 0 & 0 & 0 & 0 & 0 & 0 & 0 & 0 & 0 & 0 \\
\hline 2 & 0 & 0 & 0 & 0 & 0 & 0 & 0 & 0 & 0 & 0 \\
\hline 3 & 0 & 0 & 0 & 0 & 0 & 0 & 0 & 0 & 0 & 0 \\
\hline 4 & 0 & 0 & 0 & 0 & 0 & 1 & 0 & 0 & 0 & 0 \\
\hline 5 & 0 & 0 & 0 & 0 & 0 & 2 & 0 & 0 & 0 & 0 \\
\hline 6 & 0 & 0 & 0 & 0 & 0 & 2 & 1 & 0 & 0 & 0 \\
\hline 7 & 0 & 0 & 0 & 0 & 0 & 3 & 0 & 0 & 0 & 0 \\
\hline 8 & 0 & 0 & 0 & 0 & 0 & 0 & 0 & 0 & 0 & 0 \\
\hline 9 & 0 & 0 & 0 & 0 & 0 & 0 & 0 & 0 & 0 & 0 \\
\hline 10 & 0 & 0 & 0 & 0 & 0 & 0 & 0 & 0 & 0 & 0 \\
\hline 11 & 0 & 0 & 0 & 0 & 0 & 0 & 0 & 0 & 0 & 0 \\
\hline 12 & 0 & 0 & 0 & 0 & 0 & 0 & 1 & 0 & 0 & 0 \\
\hline 13 & 0 & 지․ & 0 & 0 & 0 & 0 & 0 & 2 & 0 & 0 \\
\hline 14 & 0 & 0 & 0 & 0 & 0 & 0 & 1 & 1. & 0 & 0 \\
\hline 15 & 0 & 0 & 0 & 0 & 0 & 0 & 0 & 1 & 0 & 0 \\
\hline 16 & 0 & 0 & 0 & 0 & 0 & 0 & 0 & 1 & 0 & 0 \\
\hline 17 & 0 & 0 & 0 & 0 & 0 & 0 & 0 & 0 & 0 & 0 \\
\hline 18 & 0 & 0 & 0 & 0 & 0 & 0 & 0 & 0 & 0 & 0 \\
\hline 19 & 0 & 0 & 0 & 0 & 0 & 0 & 0 & 0 & 0 & 0 \\
\hline 20 & 0 & 0 & 0 & 0 & 0 & 0 & 0 & 0 & 0 & 0 \\
\hline
\end{tabular}

\section{EXPLANATION}

DENOTES THE DIFFERENCE IN ELEVATION BETWEEN THE SAMPLE DIGITAL ELEVATION MODEL AND THE MODIFIED DIGITAL ELEVATION MODEL

Figure 6. Difference in elevation obtained by subtracting cell elevations in the sample digital elevation model from cell elevations in the modified digital elevation model.

and

$$
D A J=\frac{C E-A E}{1}
$$

where

$D C O=$ distance-weighted decrease in elevation from the center cell to a corner cell, in feet per foot;

$C E=$ elevation of the center cell, in feet;

$C O=$ elevation of the corner cell, in feet;

$D A J=$ distance-weighted decrease in elevation from the center cell to an adjacent cell, in feet per foot; and

$A E=$ elevation of an adjacent cell, in feet.
For example, the cell in column 5 row 9 in figure 4 has three possible flow directions-one corner cell has a distance-weighted decrease in elevation of 4.24 feet $[(26-20) / \sqrt{2}]$, the other corner cell has a distance-weighted decrease in elevation of 0.71 foot $[(26-25) / \sqrt{2}]$, and the adjacent cell has a distance-weighted decrease in elevation of 5.0 feet $[(26-21) / 1]$. In this case, the cell is assigned a flow direction from the center cell to the adjacent cell, which has the greatest distance-weighted decrease in elevation. Most of the cells are assigned a flow direction using this first condition.

The second condition is when two or more neighboring cells have the same greatest distance-weighted decrease in elevation. In this case, flow direction is 
Table 3. Hydrologic characteristics computed from a sample digital elevation model

\begin{tabular}{ccc}
\hline Depression number & $\begin{array}{c}\text { Storage volume } \\
\text { of depression } \\
\text { (cubic feet) }\end{array}$ & $\begin{array}{c}\text { Surface area } \\
\text { of depression } \\
\text { (square feet) }\end{array}$ \\
\hline 1 & 9 & 5 \\
2 & 7 & 6 \\
\hline
\end{tabular}

\section{Column}

\begin{tabular}{|c|c|c|c|c|c|c|c|c|c|c|}
\hline Row & 1 & 2 & 3 & 4 & 5 & 6 & 7 & 8 & 9 & 10 \\
\hline 1 & 0 & 0 & 0 & 0 & 0 & 0 & 0 & 0 & 0 & 0 \\
\hline 2 & 0 & 0 & 0 & 0 & 0 & 0 & 0 & 0 & 0 & 0 \\
\hline 3 & 0 & 0 & 0 & 0 & 0 & 0 & 0 & 0 & 0 & 0 \\
\hline 4 & 0 & 0 & 0 & 0 & 0 & 1 & 0 & 0 & 0 & 0 \\
\hline 5 & 0 & 0 & 0 & 0 & 0 & 1 & 0 & 0 & 0 & 0 \\
\hline 6 & 0 & 0 & 0 & 0 & 0 & 1 & 1 & 0 & 0 & 0 \\
\hline 7 & 0 & 0 & 0 & 0 & 0 & 1 & 0 & 0 & 0 & 0 \\
\hline 8 & 0 & 0 & 0 & 0 & 0 & 0 & 0 & 0 & 0 & 0 \\
\hline 9 & 0 & 0 & 0 & 0 & 0 & 0 & 0 & 0 & 0 & 0 \\
\hline 10 & 0 & 0 & 0 & 0 & 0 & 0 & 0 & 0 & 0 & 0 \\
\hline 11 & 0 & 0 & 0 & 0 & 0 & 0 & 0 & 0 & 0 & 0 \\
\hline 12 & 0 & 0 & 0 & 0 & 0 & 0 & 2 & 0 & 0 & 0 \\
\hline 13 & 0 & 3 & 0 & 0 & 0 & 0 & 0 & 2 & 0 & 0 \\
\hline 14 & 0 & 0 & 0 & 0 & 0 & 0 & 2 & 2 & 0 & 0 \\
\hline 15 & 0 & 0 & 0 & 0 & 0 & 0 & 0 & 2 & 0 & 0 \\
\hline 16 & 0 & 0 & 0 & 0 & 0 & 0 & 0 & 2 & 0 & 0 \\
\hline 17 & 0 & 0 & 0 & 0 & 0 & 0 & 0 & 0 & 0 & 0 \\
\hline 18 & 0 & 0 & 0 & 0 & 0 & 0 & 0 & 0 & 0 & 0 \\
\hline 19 & 0 & 0 & 0 & 0 & 0 & 0 & 0 & 0 & 0 & 0 \\
\hline 20 & 0 & 0 & 0 & 0 & 0 & 0 & 0 & 0 & 0 & 0 \\
\hline
\end{tabular}

Figure 7. Unique nonzero values used to identify groups of cells that comprise depressions in the depression mask data set.

specified in a table. For instance, if three adjacent cells along the edge of the neighborhood have the same distanceweighted decrease in elevation, the center cell arbitrarily is assigned the flow direction. If two cells on opposite sides of the center cell have the same distance-weighted decrease in elevation, one cell arbitrarily is assigned the flow direction.

The third condition is when all neighboring cells have the same distance-weighted decrease in elevation. When the third condition occurs, the neighborhood is representative of a flat ground surface, and the direction of flow to the outlet cell location is not known by examining only the eight neighboring cell elevations. The flow direction for cells that meet the criteria of the first or second condition is determined first, and then the flow direction of cells that meet the third condition is determined by an iterative process. In each iteration, cells that have not been assigned 


$\begin{array}{rrrrrrrrrrr}1 & 2 & 2 & 2 & 2 & 4 & 8 & 32 & 64 & 16 & 16 \\ 2 & 1 & 2 & 2 & 2 & 4 & 8 & 32 & 16 & 8 & 8 \\ 3 & 2 & 2 & 2 & 2 & 2 & 8 & 32 & 16 & 16 & 16 \\ 4 & 2 & 2 & 2 & 2 & 2 & 8 & 32 & 32 & 32 & 32 \\ 5 & 2 & 2 & 2 & 2 & 2 & 8 & 8 & 32 & 32 & 64 \\ 6 & 2 & 2 & 2 & 2 & 2 & 8 & 16 & 32 & 32 & 32 \\ 7 & 4 & 4 & 2 & 2 & 2 & 8 & 32 & 32 & 64 & 32 \\ 8 & 2 & 4 & 4 & 4 & 4 & 8 & 16 & 16 & 16 & 16 \\ 9 & 2 & 2 & 2 & 2 & 2 & 8 & 32 & 32 & 32 & 32 \\ 10 & 1 & 1 & 2 & 2 & 2 & 4 & 32 & 16 & 32 & 32 \\ 11 & 4 & 1 & 1 & 2 & 2 & 4 & 8 & 32 & 32 & 16 \\ 12 & 4 & 8 & 2 & 2 & 2 & 2 & 8 & 32 & 32 & 16 \\ 13 & 2 & 1 & 1 & 2 & 2 & 2 & 8 & 8 & 32 & 32 \\ 14 & 1 & 128 & 1 & 1 & 2 & 2 & 4 & 8 & 32 & 32 \\ 15 & 128 & 128 & 128 & 1 & 1 & 2 & 128 & 8 & 32 & 32 \\ 16 & 128 & 128 & 1 & 1 & 1 & 2 & 2 & 4 & 8 & 32 \\ 17 & 4 & 8 & 8 & 4 & 2 & 2 & 2 & 8 & 8 & 32 \\ 18 & 4 & 8 & 8 & 8 & 4 & 2 & 2 & 8 & 16 & 32 \\ 19 & 4 & 4 & 4 & 8 & 4 & 2 & 2 & 8 & 16 & 32 \\ 20 & 2 & 2 & 2 & 4 & 4 & 4 & 8 & 8 & 32 & 32\end{array}$

Figure 8. Flow direction values assigned to cells in the sample digital elevation model.

a flow direction are set to flow into a neighboring cell that has a flow direction that does not point back to the newly assigned cell. Thus, this iterative procedure creates flow direction assignments to cells that expand into the flat cells by using the flat cell's outlet cell location. The procedure is repeated until all cells have a flow direction assigned.

The initialized drainage area mask (fig. 7) and the flow direction data set (fig. 8) are processed iteratively. On each pass, all possible zero-value cells in the drainage area mask receive a label if the flow path connects the cell to a labeled cell. All border cells in the drainage area mask are assigned a unique value, and cells that flow to the edges of the digital elevation model will have this unique value.

\section{Procedure 5}

The function of procedure 5 is to compute the hydrologic characteristics for the subbasins. The drainage area for each subbasin was computed by counting the number of cells in the subbasin and multiplying by the surface area of a cell. The total storage volume of a subbasin was computed by (1) Subtracting cell elevations in the sample digital elevation model from cell elevations in the modified digital elevation model to obtain the depth, (2) multiplying the depth obtained in step 1 by the surface area of each cell, and (3) summing all values obtained in step 2 to estimate the total storage volume of the subbasin. Thus, the total storage volume of a subbasin includes the storage volume of smaller depressions not selected in procedure 3 as well as the storage volume of the major depression for which the drainage area was delineated.

The outlet location and elevation of each subbasin also are computed in procedure 5. For all subbasins that share a common divide, the outlet location was determined by examining all pairs of connected cells on either side of the common divide. The location and maximum elevation of each pair of cells are determined and saved in a temporary computer file. The minimum elevation in the temporary file is the outlet elevation of the common divide. Because the same elevation may occur at more than one 


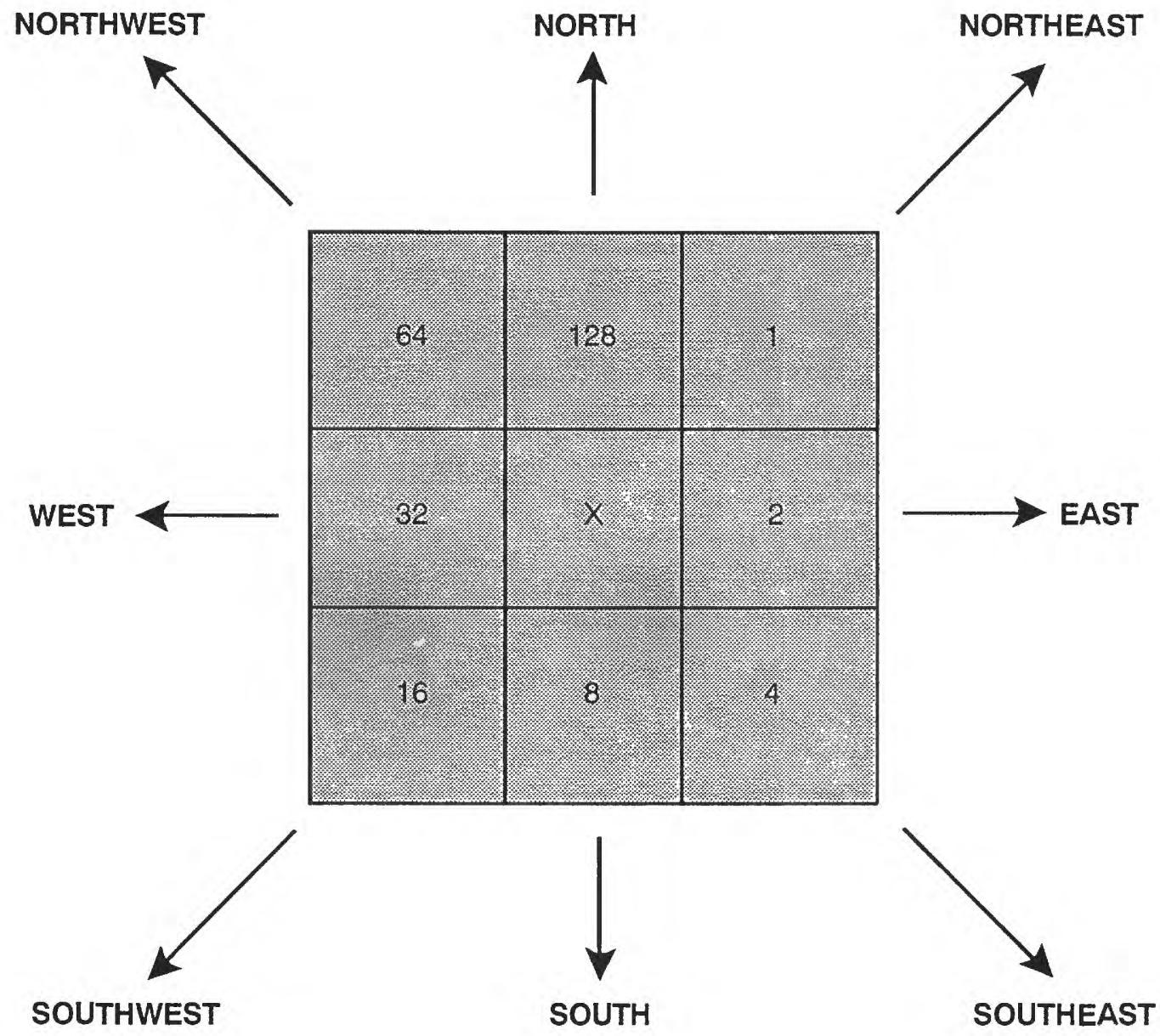

EXPLANATION

64 NUMBERS ARE IDENTIFICATION NUMBERS USED TO ASSIGN FLOW DIRECTIONS

Figure 9. Eight possible flow directions assigned to a cell and their orientation.

location, more than one outlet from a subbasin can occur. In the case of multiple outlets from a subbasin, the user can specify the outlet to a downstream subbasin.

The assignment of cells to drainage subbasins is shown in figure 10, and the drainage-basin linkages are listed in table 4 . The row and column of outlet locations and the outlet elevations for the sample digital elevation model are listed in table 4. As indicated in table 4, subbasin 2 shares common boundaries with subbasins 1,3 , and 0 , which flows off the edge of the digital elevation model. Of the three possible outlet elevations for subbasin 2 , the outlet to subbasin 0 has the minimum elevation. Therefore, subbasin 0 would be chosen as the downstream link for subbasins 1 and 2 and subbasin 2 would be the downstream link for subbasin 3 .

\section{HYDROLOGIC CHARACTERISTICS}

\section{Depth, Surface Area, and Storage Volume Relations}

An ordinary least-squares-regression equation was developed for each test site to determine if there is a large degree of correlation between depth and storage volume and between depth and surface area. If a large degree of correlation exists between depth and storage volume, then storage volume in a basin could be computed by making relatively simple depth measurements. Two regression equations were developed for each test site using depth as 


\begin{tabular}{|c|c|c|c|c|c|c|c|c|c|c|}
\hline \multicolumn{11}{|c|}{ Column } \\
\hline Row & 1 & 2 & 3 & 4 & 5 & 6 & 7 & 8 & 9 & 10 \\
\hline 1 & 1 & 1 & 1 & 1 & 1 & 1 & 1 & 0 & 1 & 1 \\
\hline 2 & 1 & 1 & 1 & 1 & 1 & 1 & 1 & 1 & 1 & 1 \\
\hline 3 & 1 & 1 & 1 & 1 & 1 & 1 & 1 & 1 & 1 & 1 \\
\hline 4 & 1 & 1 & 1 & 1 & 1 & 1 & 1 & $\overrightarrow{1}$ & 1 & 1 \\
\hline 5 & 1 & 1 & 1 & 1 & 1 & 1 & 1 & 1 & 1 & 1 \\
\hline 6 & 1 & 1 & 1 & 1 & 1 & 1 & 1 & 1 & 1 & 1 \\
\hline 7 & 2 & 2. & 1 & 1 & 1 & 1 & 1 & 1 & 1 & 1 \\
\hline 8 & 2. & 2. & 2 & 2 & 2 & 2 & 2 & 2 & 2 & 2. \\
\hline 9 & 2 & 2 & 2 & 2 & 2 & 2 & 2 & 2 & 2 & 2 \\
\hline 10 & 2 & 2 & 2 & 2 & 2 & 2 & 2 & 2 & 2 & 2 \\
\hline 11 & . & 2 & 2 & 2 & 2 & 2 & 2 & 2 & 2 & 2 \\
\hline 12 & 3 & 3 & 2 & 2 & 2 & 2 & 2 & 2 & 2 & 2 \\
\hline 13 & 3. & (3) & 2 & 2 & 2 & 2 & 2 & 2 & 2 & 2 \\
\hline 14 & 3 & 3 & 2. & 2 & 2 & 2 & 2 & 2. & 2 & 2 \\
\hline 15 & 3 & 3 & 2 & 2 & 2. & 2 & 2 & 2 & 2 & 2 \\
\hline 16 & 3 & . & 2. & 2 & 2 & 2 & 2 & 2 & 0 & 0 \\
\hline 17 & 0 & 0 & 0 & 0 & 0 & 0 & 0 & 0 & -0 & 0 \\
\hline 18 & 0 & 0 & 0 & 0 & 0 & 0 & 0 & 0 & 0 & 0 \\
\hline 19 & 0 & 0 & 0 & 0 & 0 & 0 & 0 & 0 & 0 & 0 \\
\hline 20 & 0 & 0 & 0 & 0 & 0 & 0 & 0 & 0 & 0 & 0 \\
\hline
\end{tabular}

\section{EXPLANATION}

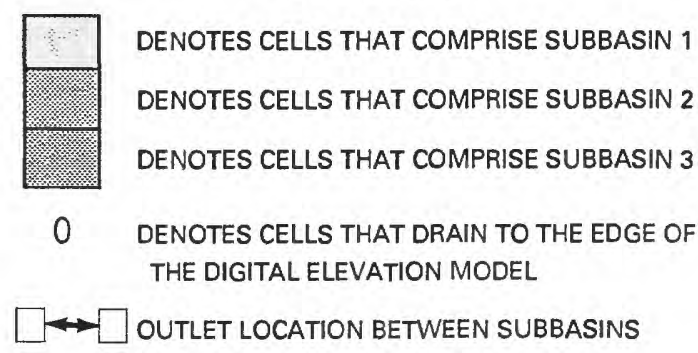

Figure 10. Assignment of cells in the sample digital elevation model to drainage subbasins.

the independent variable and the logarithms of storage volume and surface area as the dependent variables (table 5).

At test sites 4 and 5, a poor relation (a coefficient of determination less than or equal to 0.59 ) exists between depth and storage volume and depth and surface area. The coefficient of determination for the regression equation developed using the logarithm of storage volume as the dependent variable is 0.51 for test site 4 and 0.59 for test site 5. The coefficient of determination for the regression equation developed using the logarithm of surface area as the dependent variable is 0.21 for test site 4 and 0.43 for test site 5 . For test sites 2, 3, and 6, a fair relation (a coefficient of determination greater than or equal to 0.59 ) exists between depth and storage volume and depth and surface area, but the correlation is not as strong as that reported by 
Table 4. Drainage-basin linkages, outlet locations of common divides, and outlet elevations

\begin{tabular}{cccccc}
\hline $\begin{array}{c}\text { Drainage- } \\
\text { basin linkages }\end{array}$ & \multicolumn{3}{c}{ Outlet location } & Outlet elevation \\
\cline { 2 - 4 } among subbasins & Row & Column & Row & Column & (feet) \\
\hline 1 and 2 & 7 & 6 & 8 & 6 & 25 \\
2 and 3 & 12 & 3 & 13 & 2 & 43 \\
0 and 2 & 17 & 9 & 16 & 8 & 19 \\
0 and 3 & 17 & 3 & 16 & 2 & 92 \\
\hline
\end{tabular}

Table 5. Regression equations of depth, surface area, and storage volume relations for five test sites in the James River basin

$[D$, depth; $V$, storage volume; $A$, surface area]

\begin{tabular}{ccc}
\hline $\begin{array}{l}\text { Test } \\
\text { site } \\
\text { number } \\
\text { Coefficient of } \\
\text { determination }\end{array}$ & Equation \\
\hline 2 & 0.71 & $\log V=0.022+0.274(D)$ \\
2 & .60 & $\log A=0.189+0.217(D)$ \\
3 & .76 & $\log V=-0.292+0.446(D)$ \\
3 & .64 & $\log A=0.215+0.287(D)$ \\
4 & .51 & $\log V=0.425+0.290(D)$ \\
4 & .21 & $\log A=0.674+0.122(D)$ \\
5 & .59 & $\log V=0.421+0.181(D)$ \\
5 & .43 & $\log A=0.498+0.115(D)$ \\
6 & .74 & $\log V=-0.274+0.371(D)$ \\
6 & .59 & $\log A=0.191+0.233(D)$
\end{tabular}

Haan and Johnson (1967) in their study of potholes on glacial topography in Iowa. One possible explanation is that potholes in the James River basin are not as uniform in shape as the potholes investigated by Haan and Johnson (1967) in Iowa.

\section{Comparison Among Test Sites}

Special-purpose algorithms were used to delineate subbasins (pl. 1, parts $A-F$ ) in the test sites. Subbasin identification numbers are shown as a two- or three-digit integer, and outlet elevations and flow direction from a subbasin also are shown.

After subbasins were delineated, hydrologic characteristics were computed using digital elevation models developed from 4,800-foot aerial photographs (table 6). The total drainage area delineated for the test sites ranges from 2.62 square miles for test site 2 to 10.2 square miles for test site 5 . Subbasins delineated within the test sites range from 0.05 to 2.40 square miles. 
Table 6. Hydrologic characteristics computed using digital elevation models developed from 4,800-foot aerial photographs

\begin{tabular}{|c|c|c|c|c|}
\hline $\begin{array}{l}\text { Test site } \\
\text { number }\end{array}$ & $\begin{array}{l}\text { Total drainage } \\
\text { area of } \\
\text { subbasins } \\
\text { (square miles) }\end{array}$ & $\begin{array}{l}\text { Total storage volume } \\
\text { of all depressions } \\
\text { (acre-feet) }\end{array}$ & $\begin{array}{l}\text { Storage volume of } \\
\text { depressions having } \\
\text { storage greater } \\
\text { than } 10 \text { acre-feet } \\
\text { (acre-feet) }\end{array}$ & $\begin{array}{l}\text { Storage volume per square } \\
\text { mile of drainage area } \\
\text { contributing runoff to } \\
\text { depressions having storage } \\
\text { greater than } 10 \text { acre-feet } \\
\text { (acre-feet) }\end{array}$ \\
\hline 2 & 2.62 & 866 & 653 & 249 \\
\hline 3 & 3.17 & 1,020 & 879 & 277 \\
\hline 4 & 5.24 & 1,710 & 1,410 & 269 \\
\hline 5 & 10.2 & 8,260 & 7,290 & 715 \\
\hline 6 & 5.17 & 1,030 & 606 & 117 \\
\hline
\end{tabular}

Drainage areas were delineated for all depressions that have a storage volume greater than 10 acre-feet. Storage volume of depressions having storage greater than 10 acre-feet ranges from 606 acre-feet in test site 6 to 7,290 acre-feet in test site 5. Test sites 2, 3, and 4 have about the same storage volume per square mile $(249,277$, and 269 acre-feet, respectively), but test site 5 has a storage volume of 715 acre-feet per square mile and test site 6 only has a storage volume of 117 acre-feet per square mile.

The ratio of the storage volume of depressions, in acre-feet, divided by the surface area of depressions, in acres, provides a measure of the mean depth. Depressions located in test site 5 have a mean depth of 4.25 feet, and depressions located in test site 6 have a mean depth of 1.86 feet. Thus, the greater storage volume of depressions located in test site 5 is at least partially attributable to the relatively deep depressions. Test site 6 , which has the most uniform topography, has shallow depressions, which decrease the potential storage volume in this test site.

\section{Comparison Among Digital Elevation Models}

The subbasins delineated for test site 4 using the digital elevation model developed from 7.5-minute topographic maps have a much different shape and area than the subbasins delineated using the digital elevation models developed from 4,800-foot and 9,600-foot aerial photographs. The total drainage area delineated for test site 4 using the digital elevation model developed from 7.5minute topographic maps was 4.22 square miles. The total drainage area delineated using the digital elevation model developed from 4,800-foot aerial photographs was 5.24 square miles. The total drainage area delineated using the digital elevation model developed from 9,600-foot aerial photographs was 6.37 square miles. Although the outlet locations and elevations of the different subbasins in test site 4 computed using the digital elevation models developed from 4,800-foot and 9,600-foot aerial photographs are notably more similar to each other (pl. 1, part $F$ ) than to those computed using the digital elevation model developed from 7.5-minute topographic maps, there are many differences.

Comparison of hydrologic characteristics computed using digital elevation models developed from 7.5-minute topographic maps, 4,800-foot aerial photographs, and 9,600 -foot aerial photographs indicates that substantial differences in the storage volume of depressions occur among the digital elevation models. Because different subbasin shapes and areas were delineated for each test site using the various digital elevation models, the total storage volume of depressions in a test site was divided by the drainage area delineated in a test site to compute the storage volume per square mile. The storage volume computed for test site 4 using the digital elevation model developed from 7.5 -minute topographic maps is 673 acre-feet per square mile of area draining to depressions. The storage volume computed using the digital elevation model developed from 4,800 -foot aerial photographs is 274 acre-feet per square mile. The storage volume computed using the digital elevation model developed from 9,600-foot aerial photographs is 320 acre-feet per square mile.

Many factors may be attributable to the difference in storage volume among the different digital elevation models (Goldberg and others, 1987). One of the apparent factors is the change in topography that might have occurred between 
the time the 7.5-minute topographic maps were compiled (1950) and the time the 4,800-foot and 9,600-foot aerial photographs were made (1985). Agricultural practices in the James River basin could cause some of the depressions to be drained, smoothed, or filled. These practices can have an effect on storage volume, especially in the shallow depressions that have large surface areas. Another factor attributed to the difference in storage volume is the manner in which the contours were compiled. A greater number of contours were drawn from the digital elevation models developed from 4,800-foot and 9,600-foot aerial photographs than from the model developed from 7.5minute topographic maps. The greater number of contours increased the definition of the topographic surface (Goldberg and others, 1987).

\section{Comparison of Contributing and Noncontributing Drainage Areas}

Delineation of contributing and noncontributing drainage areas is a difficult task that requires a large amount of subjective judgment and knowledge of the hydrology of the area to be delineated. Computer programs previously discussed that were used to compute hydrologic characteristics can be used to determine changes in contributing and noncontributing drainage areas that occur under different runoff conditions.

If the drainage area of a subbasin and the storage volume of a depression that drains the subbasin are known and if a uniform depth of runoff is assumed to occur, then the total runoff into a depression can be computed and checked against the volume of water required to fill the depression. Runoff from a subbasin is contained either in whole or in part in the depression draining the subbasin, and runoff not contained in the depression contributes to a downstream subbasin. Hydrologic computations based on the digital elevation model developed from 9,600-foot aerial photographs for subbasins in test site 4 for a 1.0-inch runoff are listed in table 7 . Runoff from subbasin 368 (pl. 1, part $F$ ) is 33.7 acre-feet, of which 20.9 acre-feet went into storage by filling the depression and 12.8 acre-feet was outflow from subbasin 368 to subbasin 262. About 11.5 acre-feet of runoff originated from subbasin 262 and was added to the 12.8 acre-feet of inflow from subbasin 368 to produce a total inflow of 24.3 acre-feet to the depression draining subbasin 262. The total runoff (24.3 acre-feet) was contained in the depression draining subbasin 262 .

The total runoff not contained in the subbasins delineated in test site 4 for a 1.0-inch runoff was 18.5 acre-feet, of which 2.4 acre-feet was outflow from the subbasins and either was retained in storage in a downstream basin (not delineated) or entered a tributary of the James River. The 2.4 acre-feet of runoff in excess of depressional storage volume originated entirely within sub- basin 174. Thus, if runoff from the test site is assumed to contribute to the James River through its tributaries, then 0.40 square mile of the total 6.37 -square-mile drainage area in test site 4 would change from noncontributing to contributing.

Computations based on the digital elevation model developed from 9,600-foot aerial photographs for subbasins in test site 4 for a 3.0-inch runoff are listed in table 8 . A schematic diagram of the contributing and noncontributing subbasins in test site 4 is shown in figure 11 . The total runoff to subbasins delineated in test site 4 is about 1,020 acre-feet, but only 280 acre-feet of runoff flowed out of test site 4. Subbasin 899 contributed 33.4 acre-feet of water to subbasin 839 , but the storage volume of subbasin 839 was greater than the outflow from subbasin 899 and the runoff that originates in subbasin 839 . The contributing drainage area from all the subbasins delineated in test site 4 for a 3.0-inch runoff is 3.39 square miles, an increase of 2.99 square miles compared to the 0.40 square mile for a 1.0 -inch runoff. Thus, digital elevation models, in conjunction with data-management software, can be used to examine contributing and noncontributing drainage areas for various runoff depths.

\section{SUMMARY AND CONCLUSIONS}

The James River, about 747 miles in length, drains parts of east-central North Dakota and South Dakota. The James River basin encompasses about 6,200 square miles in North Dakota. The drainage area upstream of Jamestown Reservoir is 1,760 square miles, of which about 1,010 square miles is considered noncontributing. Two major problems occur when delineating drainage areas in the James River basin using conventional techniques. First, it is difficult to determine drainage-area boundaries, especially at the divide where the James River, Missouri River, and Hudson Bay drainages meet. Second, it is difficult to differentiate between areas that contribute surface runoff to the James River and areas that do not contribute surface runoff, but are still within the James River basin.

In the late 1950's, a need for additional hydrologic information developed because depressional storage areas were being drained for agricultural use. As a result of this additional need, several studies aimed at computing individual hydrologic characteristics were completed, but little work was done to determine drainage-basin linkages among depressional storage areas. Damage from extreme floods on the upper Mississippi River in 1965 focused attention on the runoff processes of drainage basins characterized by numerous potholes.

Many studies were conducted during 1970-84 to delineate drainage basins using digital elevation models as source material. Each of the studies provided new methods of deriving hydrologic information from digital elevation 
Table 7. Inflow to and outflow from subbasins in test site 4 for a 1.0-inch runoff computed using a digital elevation model developed from 9,600-foot aerial photographs

\begin{tabular}{|c|c|c|c|c|c|c|}
\hline $\begin{array}{c}\text { Subbasin } \\
\text { number }\end{array}$ & $\begin{array}{c}\text { Downstream } \\
\text { link }\end{array}$ & $\begin{array}{l}\text { Total storage } \\
\text { volume of } \\
\text { depression } \\
\text { (acre-feet) }\end{array}$ & $\begin{array}{l}\text { Inflow from } \\
\text { upstream } \\
\text { subbasins } \\
\text { (acre-feet) }\end{array}$ & $\begin{array}{l}\text { Runoff from } \\
\text { subbasin } \\
\text { (acre-feet) }\end{array}$ & $\begin{array}{c}\text { Volume } \\
\text { stored in } \\
\text { depression } \\
\text { (acre-feet) }\end{array}$ & $\begin{array}{l}\text { Outflow from } \\
\text { subbasin } \\
\text { (acre-feet) }\end{array}$ \\
\hline $\begin{array}{l}174 \\
239 \\
290 \\
258 \\
262\end{array}$ & $\begin{array}{r}0 \\
290 \\
379 \\
174 \\
0\end{array}$ & $\begin{array}{l}19.1 \\
21.2 \\
26.0 \\
16.7 \\
55.0\end{array}$ & $\begin{array}{c}0 \\
0 \\
0 \\
0 \\
12.8\end{array}$ & $\begin{array}{r}21.5 \\
5.3 \\
22.9 \\
3.6 \\
11.5\end{array}$ & $\begin{array}{r}19.1 \\
5.3 \\
22.9 \\
3.6 \\
24.3\end{array}$ & $\begin{array}{l}2.4 \\
0 \\
0 \\
0 \\
0\end{array}$ \\
\hline $\begin{array}{l}368 \\
313 \\
379 \\
340 \\
318\end{array}$ & $\begin{array}{l}262 \\
368 \\
498 \\
368 \\
174\end{array}$ & $\begin{array}{l}20.9 \\
22.7 \\
29.0 \\
15.4 \\
15.9\end{array}$ & $\begin{array}{l}0 \\
0 \\
0 \\
0 \\
0\end{array}$ & $\begin{array}{r}33.7 \\
4.3 \\
8.5 \\
6.1 \\
1.6\end{array}$ & $\begin{array}{r}20.9 \\
4.3 \\
8.5 \\
6.1 \\
1.6\end{array}$ & $\begin{array}{c}12.8 \\
0 \\
0 \\
0 \\
0\end{array}$ \\
\hline $\begin{array}{l}498 \\
517 \\
499 \\
522 \\
601\end{array}$ & $\begin{array}{l}499 \\
498 \\
368 \\
368 \\
522\end{array}$ & $\begin{array}{r}31.5 \\
55.6 \\
34.1 \\
35.9 \\
132\end{array}$ & $\begin{array}{l}0 \\
0 \\
2.2 \\
0 \\
0\end{array}$ & $\begin{array}{r}33.7 \\
23.1 \\
4.6 \\
5.5 \\
10.7\end{array}$ & $\begin{array}{r}31.5 \\
23.1 \\
6.8 \\
5.5 \\
10.7\end{array}$ & $\begin{array}{l}2.2 \\
0 \\
0 \\
0 \\
0\end{array}$ \\
\hline $\begin{array}{l}609 \\
618 \\
635 \\
648 \\
703\end{array}$ & $\begin{array}{l}498 \\
609 \\
601 \\
618 \\
618\end{array}$ & $\begin{array}{c}39.6 \\
83.3 \\
174 \\
815 \\
93.0\end{array}$ & $\begin{array}{l}0 \\
0 \\
0 \\
0 \\
0\end{array}$ & $\begin{array}{r}36.5 \\
9.5 \\
7.5 \\
33.9 \\
2.6\end{array}$ & $\begin{array}{r}36.5 \\
9.5 \\
7.5 \\
33.9 \\
2.6\end{array}$ & $\begin{array}{l}0 \\
0 \\
0 \\
0 \\
0\end{array}$ \\
\hline $\begin{array}{l}744 \\
797 \\
863 \\
839 \\
899\end{array}$ & $\begin{array}{l}609 \\
744 \\
648 \\
797 \\
839\end{array}$ & $\begin{array}{r}97.2 \\
62.0 \\
27.0 \\
104 \\
15.1 \\
\end{array}$ & $\begin{array}{l}0 \\
0 \\
0 \\
1.0 \\
0 \\
\end{array}$ & $\begin{array}{r}14.8 \\
5.8 \\
7.0 \\
9.2 \\
16.2 \\
\end{array}$ & $\begin{array}{r}14.8 \\
5.8 \\
7.0 \\
10.2 \\
15.1 \\
\end{array}$ & $\begin{array}{l}0 \\
0 \\
0 \\
0 \\
1.1\end{array}$ \\
\hline Total & & $2,041.2$ & 16.0 & 339.6 & 337.1 & \\
\hline
\end{tabular}

models; however, none of the studies provided a technique to link the subbasins occurring in topography characteristic of the James River basin.

Five test sites that are representative of the topography and the drainage patterns of the James River basin were selected to develop digital elevation models. Two digital elevation models were developed for each test site from 7.5-minute topographic maps and 4,800-foot aerial photographs. An additional digital elevation model was developed for test site 4 from 9,600-foot aerial photographs. The total cost of developing the digital elevation model for test site 4 from 7.5-minute topographic maps averaged $\$ 155$ per square mile. The total cost of developing the digital elevation model for test site 4 from 4,800-foot aerial photographs was about $\$ 740$ per square mile. The total cost of developing the digital elevation model for test site 4 from 9,600 -foot aerial photographs was about $\$ 520$ per square mile.
A collection of computer programs was modified and used to compute hydrologic characteristics from digital elevation model data. Five procedures were used to determine: (1) outlet elevations of subbasins; (2) drainage areas of subbasins; (3) drainage-basin linkages among subbasins; and (4) elevation, storage volume, and surface area relations of subbasins.

Drainage areas of subbasins in the test sites were delineated for each digital elevation model. The total drainage area delineated for the test sites ranged from 2.62 to 10.2 square miles. Separate drainage areas were delineated for all depressions that have a storage volume greater than 10 acre-feet. Storage volume of depressions having storage greater than 10 acre-feet ranges from 117 acre-feet per square mile in test site 6 to 715 acre-feet per square mile in test site 5 .

Total runoff of subbasins contributing runoff to depressions in test site 4 was computed for a 1.0 -inch runoff 
Table 8. Inflow to and outflow from subbasins in test site 4 for a 3.0-inch runoff computed using a digital elevation model developed from 9,600-foot aerial photographs

\begin{tabular}{|c|c|c|c|c|c|c|}
\hline $\begin{array}{c}\text { Subbasin } \\
\text { number }\end{array}$ & $\begin{array}{c}\text { Downstream } \\
\text { link }\end{array}$ & $\begin{array}{c}\text { Total storage } \\
\text { volume of } \\
\text { depression } \\
\text { (acre-feet) }\end{array}$ & $\begin{array}{l}\text { Inflow from } \\
\text { upstream } \\
\text { subbasins } \\
\text { (acre-feet) }\end{array}$ & $\begin{array}{l}\text { Runoff from } \\
\text { subbasin } \\
\text { (acre-feet) }\end{array}$ & $\begin{array}{l}\text { Volume } \\
\text { stored in } \\
\text { depression } \\
\text { (acre-feet) }\end{array}$ & $\begin{array}{l}\text { Outflow from } \\
\text { subbasin } \\
\text { (acre-feet) }\end{array}$ \\
\hline $\begin{array}{l}174 \\
239 \\
290 \\
258 \\
262\end{array}$ & $\begin{array}{r}0 \\
290 \\
379 \\
174 \\
0\end{array}$ & $\begin{array}{l}19.1 \\
21.2 \\
26.0 \\
16.7 \\
55.0\end{array}$ & $\begin{array}{r}0 \\
0 \\
0 \\
0 \\
255\end{array}$ & $\begin{array}{l}64.4 \\
15.9 \\
68.6 \\
10.8 \\
34.4\end{array}$ & $\begin{array}{l}19.1 \\
15.9 \\
26.0 \\
10.8 \\
55.0\end{array}$ & $\begin{array}{c}45.3 \\
0 \\
42.6 \\
0 \\
234.4\end{array}$ \\
\hline $\begin{array}{l}368 \\
313 \\
379 \\
340 \\
318\end{array}$ & $\begin{array}{l}262 \\
368 \\
498 \\
368 \\
174\end{array}$ & $\begin{array}{l}20.9 \\
22.7 \\
29.0 \\
15.4 \\
15.9\end{array}$ & $\begin{array}{c}175 \\
0 \\
42.7 \\
0 \\
0\end{array}$ & $\begin{array}{r}101 \\
12.8 \\
25.5 \\
18.4 \\
4.7\end{array}$ & $\begin{array}{r}20.9 \\
12.8 \\
29.0 \\
15.4 \\
4.7\end{array}$ & $\begin{array}{c}255.1 \\
0 \\
39.2 \\
3.0 \\
0\end{array}$ \\
\hline $\begin{array}{l}498 \\
517 \\
499 \\
522 \\
601\end{array}$ & $\begin{array}{l}499 \\
498 \\
368 \\
368 \\
522\end{array}$ & $\begin{array}{l}31.5 \\
55.6 \\
34.1 \\
35.9 \\
132\end{array}$ & $\begin{array}{r}123 \\
0 \\
192 \\
0 \\
0\end{array}$ & $\begin{array}{l}101 \\
69.4 \\
13.7 \\
16.6 \\
32.2\end{array}$ & $\begin{array}{l}31.5 \\
55.6 \\
34.1 \\
16.6 \\
32.2\end{array}$ & $\begin{array}{c}192.5 \\
13.8 \\
171.6 \\
0 \\
0\end{array}$ \\
\hline $\begin{array}{l}609 \\
618 \\
635 \\
648 \\
703\end{array}$ & $\begin{array}{l}498 \\
609 \\
601 \\
618 \\
618\end{array}$ & $\begin{array}{l}39.6 \\
83.3 \\
174 \\
815 \\
93.0\end{array}$ & $\begin{array}{l}0 \\
0 \\
0 \\
0 \\
0\end{array}$ & $\begin{array}{c}110 \\
28.4 \\
22.6 \\
102 \\
7.8\end{array}$ & $\begin{array}{c}39.6 \\
28.4 \\
22.6 \\
102 \\
7.8\end{array}$ & $\begin{array}{l}70.4 \\
0 \\
0 \\
0 \\
0\end{array}$ \\
\hline $\begin{array}{l}744 \\
797 \\
863 \\
839 \\
899\end{array}$ & $\begin{array}{l}609 \\
744 \\
648 \\
797 \\
839\end{array}$ & $\begin{array}{c}97.2 \\
62.0 \\
27.0 \\
104 \\
15.1\end{array}$ & $\begin{array}{c}0 \\
0 \\
0 \\
33.4 \\
0 \\
\end{array}$ & $\begin{array}{l}44.5 \\
17.5 \\
21.0 \\
27.7 \\
48.5 \\
\end{array}$ & $\begin{array}{l}44.5 \\
17.5 \\
21.0 \\
61.1 \\
15.1 \\
\end{array}$ & $\begin{array}{c}0 \\
0 \\
0 \\
0 \\
33.4\end{array}$ \\
\hline Total & & $2,041.2$ & 821.1 & $1,019.4$ & 739.2 & \\
\hline
\end{tabular}

and a 3.0-inch runoff. For a 1.0-inch runoff, the total runoff not contained in the subbasin from which it originated was 18.5 acre-feet, of which 2.4 acre-feet flowed out of test site 4. About 0.40 square mile of the total 6.37 -square-mile drainage area delineated in test site 4 would change from noncontributing to contributing.

Total runoff of subbasins contributing runoff to depressions in test site 4 for a 3.0 -inch runoff is about 1,020 acre-feet. About 280 acre-feet of runoff flowed out of the test site; about 740 acre-feet of runoff was retained in storage. About 3.39 square miles of the total 6.37-squaremile drainage area delineated in test site 4 changed from noncontributing to contributing.

Results of this limited investigation indicate that accurate delineation of small drainage areas (less than 5 square miles) that have topography similar to the James River basin cannot be made using digital elevation models developed from 7.5-minute topographic maps. Relatively accurate delineation of larger drainage areas (greater than 5 square miles) probably could be accomplished using digital elevation models developed from 7.5-minute topographic maps. Thus, the accuracy needed for an investigation is a scale problem. Comparison of digital elevation models for a small study site in the James River basin developed from 4,800-foot and 9,600-foot aerial photographs indicates that the digital elevation model developed from 9,600-foot aerial photographs provides the best combination of production costs and accuracy.

\section{REFERENCES}

Campbell, K.L., and Johnson, H.P., 1975, Hydrologic simulation of watersheds with artificial drainage: Water Resources Research, v. 11, no. 1, p. 120-126. 


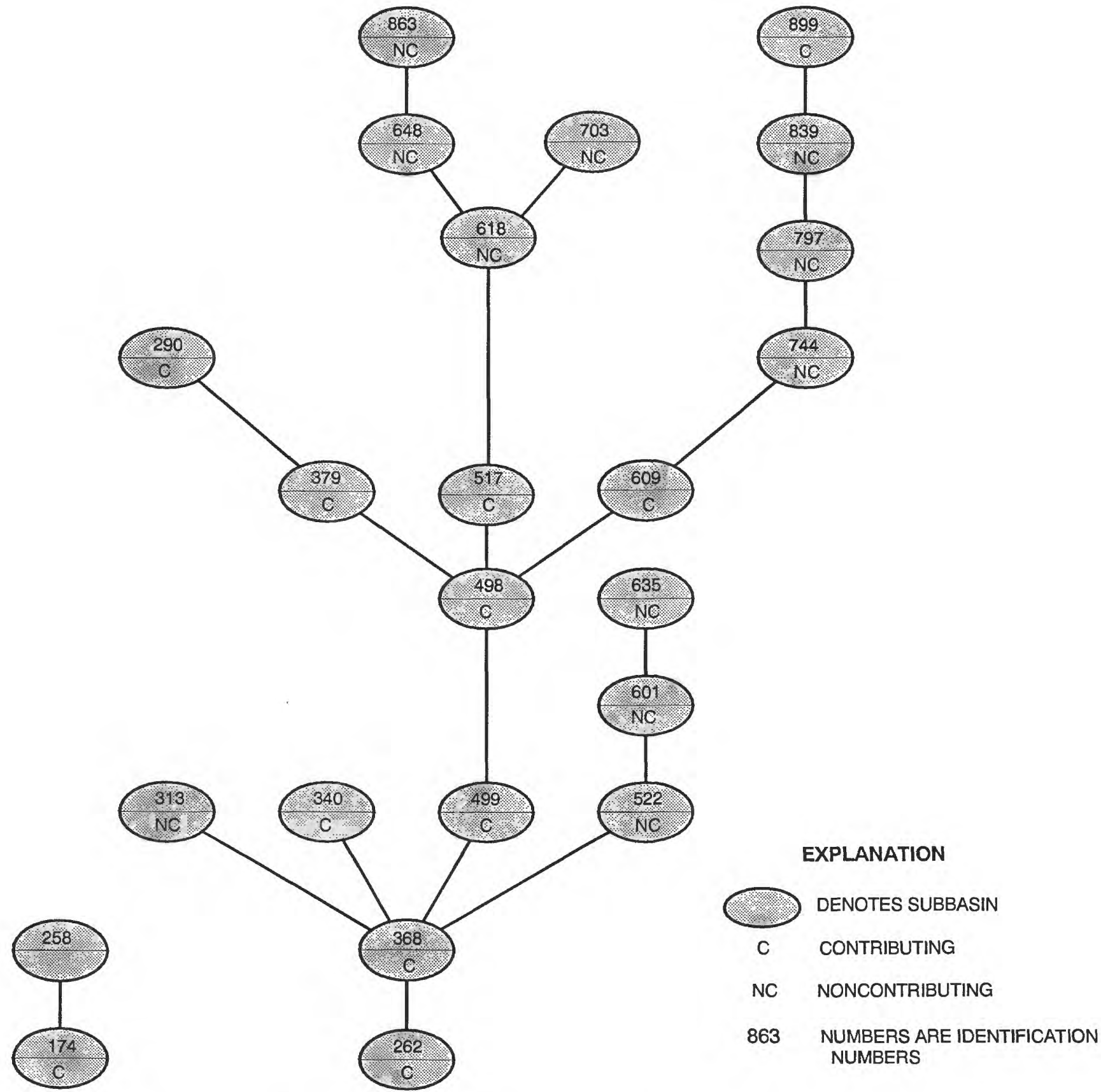

Figure 11. Contributing and noncontributing subbasin linkages in test site 4 for a 3.0 -inch runoff.

Clayton, Lee, 1967, Stagnant-glacier features of the Missouri Coteau in North Dakota, in Clayton, Lee, and Freers, T.F., eds., Glacial geology of the Missouri Coteau and adjacent areas: North Dakota Geological Survey Miscellaneous Series 30 , p. 25-46.

Collins, S.H., 1975, Terrain parameters directly from a digital terrain model: The Canadian Surveyor, v. 29, no. 3, p. $507-518$.

Collins, S.H., and Moon, G.C., 1981, Algorithms for dense digital terrain models: Photogrammetric Engineering and Remote Sensing, v. 47 , no. 1 , p. $76-81$.
DeBoer, D.W., and Johnson, H.P., 1971, Simulation of runoff from depressional characterized watersheds: Transactions of the American Society of Agricultural Engineers, v. 14, p. 615-620.

Douglas, D.D., 1986, Experiments to locate ridges and channels to create a new type of digital elevation model: Cartographica, v. 23 , no. 4 , p. 29-61.

Eisenlohr, W.S., 1972, Hydrologic investigations of prairie potholes in North Dakota, 1959-68: Hydrology of prairie potholes in North Dakota: U.S. Geological Survey Professional Paper 585-A, 102 p. 
Elassal, A.A., and Caruso, V.M., 1983, USGS digital cartographic data standards: Digital elevation models: U.S. Geological Survey Circular 895-B, 40 p.

Goldberg, J.L., Pick, T., and Wiche, G.J., 1987, The James River project: Digital elevation data supporting a hydrologic study: Proceedings of the Annual Meeting of the American Society of Photogrammetry and the American Congress on Surveying and Mapping, Baltimore, Maryland, v. 4, p. $200-211$.

Haan, C.T., 1967, Hydraulics of watersheds characterized by depressional storage: Ames, Iowa State University, unpublished Ph.D. thesis, $186 \mathrm{p}$.

Haan, C.T., and Johnson, H.P., 1967, Geometrical properties of depressions in north-central Iowa: Iowa State Journal of Science, v. 42, no. 2, p. 149-160.

1968a, Hydraulic model of runoff from depressional areas, 1, General considerations: Transactions of the American Society of Agricultural Engineers, v. 11, p. 364-367.

$1968 \mathrm{~b}$, Hydraulic model of runoff from depressional areas,

2, Development of the model: Transactions of the American Society of Agricultural Engineers, v. 11, p. 368-376.

Jenson, S.K., 1985, Automated derivation of hydrologic basin characteristics from digital elevation model data: Digital Representation of Spatial Knowledge, Proceedings of the Auto-Carto VII Symposium, American Society of Photogrammetry and the American Congress on Surveying and Mapping, p. 301-310.

Jenson, S.K., and Domingue, J.O., 1988, Extracting topographic structure from digital elevation data for geographic information system analysis: Journal of Photogrammetric Engineering and Remote Sensing, v. LIV, no. 11, p. 1593-1600.

Jenson, S.K., and Trautwein, C.M., 1987, Methods and application in surface depression analysis: Proceedings of the AutoCarto VII Symposium, American Society of Photogramme- try and the American Congress on Surveying and Mapping, p. 137-144.

Mark, D.M., 1983, Automated detection of drainage networks from digital elevation models, in Wellar, B.S., ed., Automated cartography: International Perspectives on Achievements and Challenges, v. 2, Proceedings of the Auto-Carto VI Symposium, American Society of Photogrammetry and the American Congress on Surveying and Mapping, p. 288-295.

Marks, D., Dozier, J., and Frew, J., 1984, Automated basin delineation from digital elevation data: Geo-Processing, v. 2, p. 299-311.

Miller, S.W., and Goldberg, J.L., 1984, Integration of digital cartographic data sets with other data sets for land and water resource planning: Proceedings of the Fall Technical Meeting of the American Society of Photogrammetry and the American Congress on Surveying and Mapping, San Antonio, Texas, p. 486-500.

Shjeflo, J.B., 1968, Evapotranspiration and the water budget of prairie potholes in North Dakota: Hydrology of prairie potholes in North Dakota: U.S. Geological Survey Professional Paper 585-B, 49 p.

Sloan, C.E., 1972, Ground-water hydrology of prairie potholes in North Dakota: Hydrology of prairie potholes in North Dakota: U.S. Geological Survey Professional Paper 585-C, $28 \mathrm{p.}$

Sloss, Raymond, 1971, Drainage area of Louisiana streams: Louisiana Department of Public Works, Basic Records Report No. 6, 117 p.

Stewart, R.E., and Kantrud, H.A., 1972, Vegetation of prairie potholes, North Dakota, in relation to quality of water and other environmental factors: Hydrology of prairie potholes in North Dakota: U.S. Geological Survey Professional Paper 585-D, 36 p. 
